\author{
M.A. Zhunusova ${ }^{1}$, A.Zh. Sarsenbekova ${ }^{2}$, R.M. Abdullabekova ${ }^{1}$, I.V. Figurinene ${ }^{1}$ \\ ${ }^{1}$ Karaganda State Medical University, Kazakhstan; \\ ${ }^{2}$ Ye.A. Buketov Karaganda State University, Kazakhstan \\ (E-mail: maira.zhunusova@mail.ru)
}

\title{
Comparative analysis of thermal decomposition kinetics of carbon dioxide extract from Scabiosa ochroleuca and Scabiosa isetensis at different heating rates
}

\begin{abstract}
It was presented the analysis of various calculation methods of kinetic parameters of thermal decomposition of $\mathrm{CO}_{2}$-extracts samples that were distilled from Scabiosa ochroleuca and Scabiosa isetensis according to the data of dynamic thermogravimetry. The studies were carried out in air at different heating rates (from 5 to $25 \mathrm{deg} / \mathrm{min}$ ). Experimental data of TG/DTG/HF methods were processed in accordance with the following kinetic models, namely, Friedman and Flynn-Ozawa-Wall to obtain the kinetic parameters. The use of the above mentioned models makes it possible to determine graphically the effective values of activation energy and pre-exponential factor at different heating rates of the sample and conversion degree. Non-parametric kinetic method was applied (NPK) for objective estimation of complex processes proceeding in parallel with thermal destruction. Non-parametric kinetic method (NPK) is a special approach for processing of kinetic data. Method is a new viewpoint to kinetic analysis, which is based upon rounding of results of single-stage process kinetics. Therefore, simultaneous use of data of TG/DTG/HF methods for kinetic analysis provide us with complete picture of thermal decomposition of carbonic extracts samples obtained from Scabiosa ochroleuca (cream scabious) and Scabiosa isetensis (lomelosia isetensis). In the result section of this study it is proved that the values of kinetic parameters determined by the use of different methods that correspond well with each other.
\end{abstract}

Keywords: $\mathrm{CO}_{2}$-extract, Scabiosa ochroleuca, Scabiosa isetensis, thermal analysis, thermal destruction, kinetic parameters, isoconversion method, nonparametric kinetics.

\section{Introduction}

Technological process of extracts obtaining with carbon dioxide use is considered to be environmentally-friendly method and it allows us to obtain lipophilic extracts by means of organic solvents such as extraction petrol, hexane, petroleum-ether and other. From the chemical point of view carbon dioxide is considered as a substance inert to extracted components of raw material [1]. Therefore, extraction by means of carbon dioxide can be considered as the base of creation and implementation of non-waste, environmentally-friendly producing technologies $[2,3]$. For standardization of biologically active substances (BAS) obtained by the method of carbonic extraction method we need reliable data about their physical-chemical properties. Yu.A. Lebedev et alias pointed out that the role of standardization is the most important factor of scientific and technical progress.

Within the framework of this work it was carried out the investigation of thermal conversion of $\mathrm{CO}_{2}$ extracts samples that were distilled from Scabiosa ochroleuca and Scabiosa isetensis, and study and construction of formal kinetic model by means of non-linear regression of isothermal curves.

\section{Experimental}

$\mathrm{CO}_{2}$ extraction of $S$. isetensis and $S$. ochroleuca was carried out using air-dry raw material (cut-up aerial parts of plants) at $T=291-294 \mathrm{~K}$ and pressure in $\mathrm{P}=69.76 \mathrm{~atm}$, during $16-18$ hours; the process was performed on the technical equipment «UUPE» produced by the manufacturing company «Phyto-Aromat» LLP (Almaty, Kazakhstan) (Table 1).

Ta a le 1

\section{Parameters of carbon dioxide extraction process}

\begin{tabular}{|l|c|c|c|c|c|c|}
\hline \multicolumn{1}{|c|}{$\begin{array}{c}\text { Type of SMHO (Starting } \\
\text { Materials of Herbal Origin) }\end{array}$} & Mass, g & $\begin{array}{c}\text { Number } \\
\text { of material }\end{array}$ & $\begin{array}{c}\text { Work pres- } \\
\text { sure, atm }\end{array}$ & Temperature, ${ }^{\circ} \mathrm{C}$ & Time, h & Yield, g \\
\hline S. ochroleuca & 2600 & $1^{\text {st }}$ & $69-72$ & $18-21$ & 18 & 12 \\
\cline { 3 - 8 } & 26 & $2^{\text {nd }}$ & 76 & 22 & 16 & 10 \\
\hline S. isetensis & 350 & 1 & 72 & 21 & 18 & 2 \\
\hline
\end{tabular}


Yield for $S$. isetensis is equal to $0.57 \%$, and it is equal to $0.85 \%$ for $S$. ochroleuca.

Infra-red spectra of $\mathrm{CO}_{2}$-extracts were obtained using infrared Fourier Spectrometer FSM 1201.

The study of thermal properties of $\mathrm{CO}_{2}$-extracts was performed on Labsys Evolution DTA/DSC Differential Scanning Calorimetry (DSC) produced by the «Setaram» brand in dynamic regime within temperatures range from $30^{\circ} \mathrm{C}$ to $500{ }^{\circ} \mathrm{C}$ degree during the heating rate from 5 to $25 \mathrm{deg} / \mathrm{min}$ in air in the $\mathrm{Al}_{2} \mathrm{O}_{3}$ crucible.

\section{Results and discussion}

Carried out analysis studying the growth conditions, investigation of composition and biological activity of $\mathrm{CO}_{2}$-extracts obtained from Scabiosa ochroleuca (cream scabious) and Scabiosa isetensis (lomelosia isetensis) reveal that producing of pharmaceutical products from $S$. ochroleuca and S. isetensis is very promising area in pharmaceutical technologies. The basic components of carbon dioxide extraction of $S$. isetensis and S. ochroleuca are 1.8-cineol, $\alpha$-santonin, $\alpha$-thujone, and unidentified constituent, hypothetically - steroid. $\mathrm{CO}_{2}$-extract of $S$. ochroleuca also contains $n$ - hexadecanoic acid, campesterol, and the $S$. isetensis contains $\beta$-thujone [4].

We carried out the analysis using thermogravimetry (TGA) and Differential Scanning Calorimetry (DSC) in the temperature range of $30-500{ }^{\circ} \mathrm{C}$ for two samples of $\mathrm{CO}_{2}$-extracts; it was carried out for the study of transition temperature reproducibility, and for development of formal kinetic model through the non-linear regression of isothermal curves TGA/DSC. Figure $1(a, b)$ present comparative thermal curves of weight loss (TG), the rate of weight loss (DTG) and heat effect (HF) of decomposition of $\mathrm{CO}_{2}$-extracts (Scabiosa ochroleuca and Scabiosa isetensis) at a constant heating rate $(r)$ of $10 \mathrm{deg} / \mathrm{min}$ in air flow.
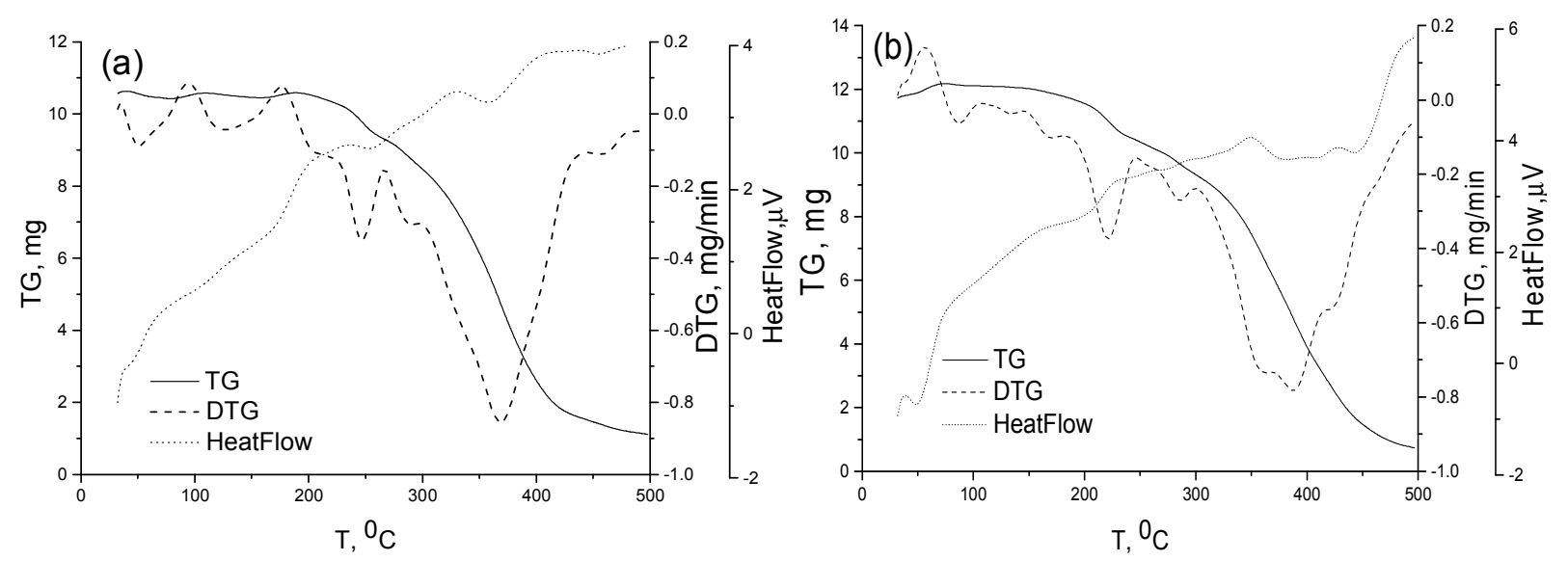

Figure 1. TG, DTG/HF curves for $\mathrm{CO}_{2}$-extracts: Scabiosa ochroleuca (a), Scabiosa isetensis (b) in air

We can see from the figure (a) that the process of decomposition of $\mathrm{CO}_{2}$-extract distilled from Scabiosa ochroleuca (cream scabious) begins at the temperature of $52^{\circ} \mathrm{C}$. Within temperatures range from $52^{\circ} \mathrm{C}$ to $100^{\circ} \mathrm{C}$ sample of $\mathrm{CO}_{2}$-extract (Scabiosa ochroleuca) loses $15 \%$ of its weight (TG curve). Analysis of DTG curves (Fig. 1, a) reveals that desorption of associated water is carried out up to temperature of $128^{\circ} \mathrm{C}$. This fact can be explained by the difficulty of breaking hydrogen bonds among water molecules and polar functional groups of $\mathrm{CO}_{2}$-extract distilled from Scabiosa ochroleuca. Then process of decomposition accelerates and weight loss at the temperature of $128-247^{\circ} \mathrm{C}$ degrees is equal to $7 \%$. On HF (Fig. 1, a) curve we can see slightly marked endothermic process that proves sample burning at the temperature of $245-369^{\circ} \mathrm{C}$ degrees.

Figure $1(a, b)$ shows that thermal decomposition of $\mathrm{CO}_{2}$-extracts: Scabiosa ochroleuca and Scabiosa isetensis is carried out in four stages. Removal of volatile substances and water is performed on the first and the second stages, thermal decomposition of the sample is on the third stage, and the removal of thermal decomposition products is on the fourth stage (Table 2). 
Thermo analytical data of analyzed $\mathrm{CO}_{2}$-extracts: Scabiosa ochroleuca and Scabiosa isetensis

\begin{tabular}{|c|c|c|c|c|c|}
\hline$\beta,{ }^{\circ} \mathrm{C} / \mathrm{min}$ & Process & $\mathrm{T}_{\mathrm{i}}\left({ }^{\circ} \mathrm{C}\right)$ & $\mathrm{T}_{\mathrm{f}}\left({ }^{\circ} \mathrm{C}\right)$ & $\mathrm{T}_{\max \text { DTG }}\left({ }^{\circ} \mathrm{C}\right)$ & $\mathrm{T}_{\operatorname{max~HF}}\left({ }^{\circ} \mathrm{C}\right)$ \\
\hline \multicolumn{6}{|c|}{ Scabiosa ochroleuca } \\
\hline \multirow{4}{*}{10} & $\mathrm{I}$ & 35 & 94 & 52 & 43 \\
\hline & II & 96 & 175 & 128 & 171 \\
\hline & III & 226 & 266 & 245 & 256 \\
\hline & IV & 302 & 432 & 367 & 359 \\
\hline \multicolumn{6}{|c|}{ Scabiosa isetensis } \\
\hline \multirow{4}{*}{10} & $\mathrm{I}$ & 59 & 103 & 86 & 48 \\
\hline & II & 191 & 244 & 222 & 206 \\
\hline & III & 246 & 302 & 284 & 288 \\
\hline & IV & 301 & 415 & 389 & 401 \\
\hline
\end{tabular}

Infra-red spectra of $\mathrm{CO}_{2}$-extracts made before dynamic thermogravimetric experiments are presented on the Figure $2(a, b)$ : Scabiosa ochroleuca $(a)$, Scabiosa isetensis $(b)$.
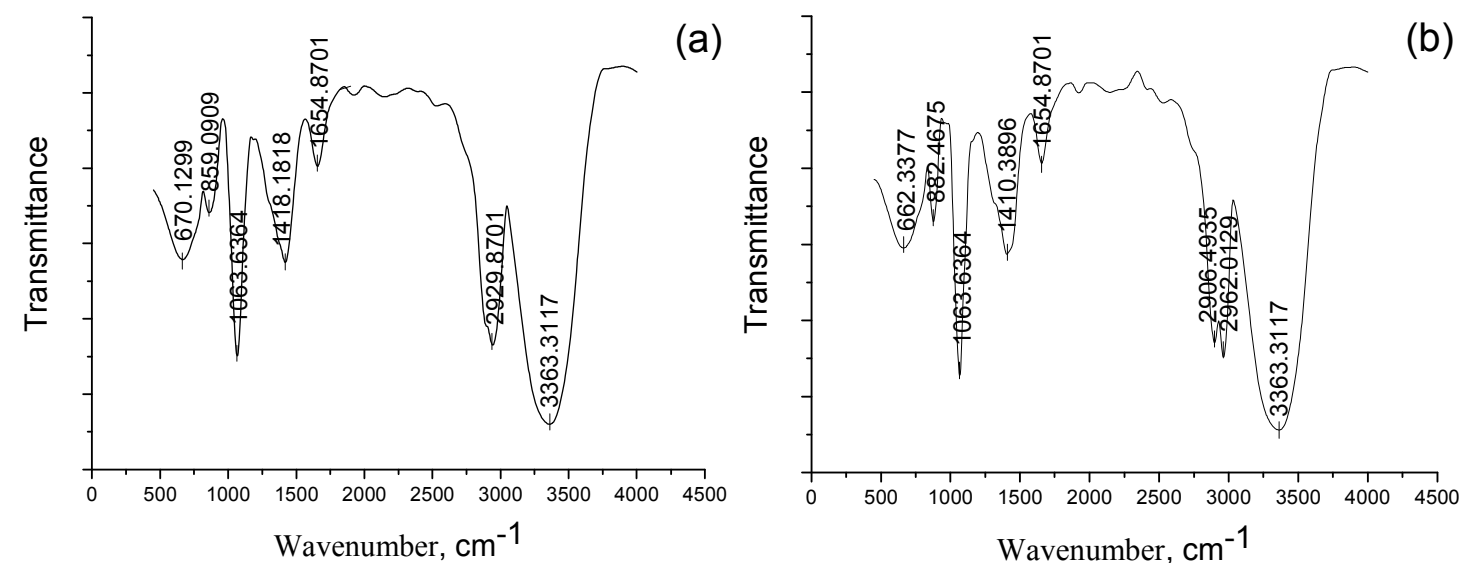

Figure 2. Infra-red spectra of $\mathrm{CO}_{2}$-extracts: Scabiosa ochroleuca (a) and Scabiosa isetensis (b)

Investigations by the use of infrared spectroscopy [5] method reveal (Fig. 2, a, b) that 2940, $1420 \mathrm{~cm}^{-1}$ are characteristic to $\mathrm{C}-\mathrm{H}$ vibrations. Infra-red spectrum of carbonyl compounds contains absorption bands $1650 \mathrm{~cm}^{-1}$ characteristic to $\mathrm{C}=\mathrm{O}$ groups. Spectrum of alcohols contains absorption bands $1420,1060 \mathrm{~cm}^{-1}$ referring to $\mathrm{C}=\mathrm{O}$ vibrations in secondary alcohol and asymmetric $\mathrm{C}-\mathrm{O}-\mathrm{C}$ aliphatic simple ethers, also valence vibrations in the area of $3350 \mathrm{~cm}^{-1}$ caused by valence vibrations of $\mathrm{O}-\mathrm{H}$ bonds (involved into hydrogen bond of $\mathrm{OH}$ group, wide band).

After thermal treatment of $\mathrm{CO}_{2}$-extracts (Scabiosa ochroleuca $(a)$ and Scabiosa isetensis $(b)$ ) the specificity of infra-red spectra changes significantly. Comparative intensity of absorption bands of groups decreases but the bands are present in the spectrum after thermogravimetric analysis.

Process of thermal decomposition is very complicated and it is comprised of decomposition of $\mathrm{CO}_{2^{-}}$ extracts (Scabiosa ochroleuca, Scabiosa isetensis) and the cause of kinetic analysis chooses.

It was carried out kinetic analysis with the use of isoconversion methods of Friedman (FR) [6] and Flynn-Ozawa-Wall (FOW) [7, 8]; it was used the method of nonparametric kinetics (NPK) [9] for the objective evaluation of complex processes running parallel to thermal decomposition.

The use of the above mentioned models makes it possible to determine graphically thermodynamic parameters of thermal decomposition of $\mathrm{CO}_{2}$-extracts, namely, Scabiosa ochroleuca, Scabiosa isetensis at different heating rates and conversion degrees (Tables $3 a$ and $3 b$ ). Graphic forms of kinetic model of one of the $\mathrm{CO}_{2}$-extract samples distilled from Scabiosa ochroleuca were presented as examples in the Figure $3(a$ and $b)$.

It should be mentioned the significant change of activation energy depending from conversion degree (Fig. 3, a). This fact revealed that decomposition process of $\mathrm{CO}_{2}$-extract distilled from Scabiosa ochroleuca occured according more than one variant of the process. In this case it will be necessary to use other kinetic method of study that will be more effective for determination and separation of these processes that are not presented in numerical expression (Fig. 3, b). 

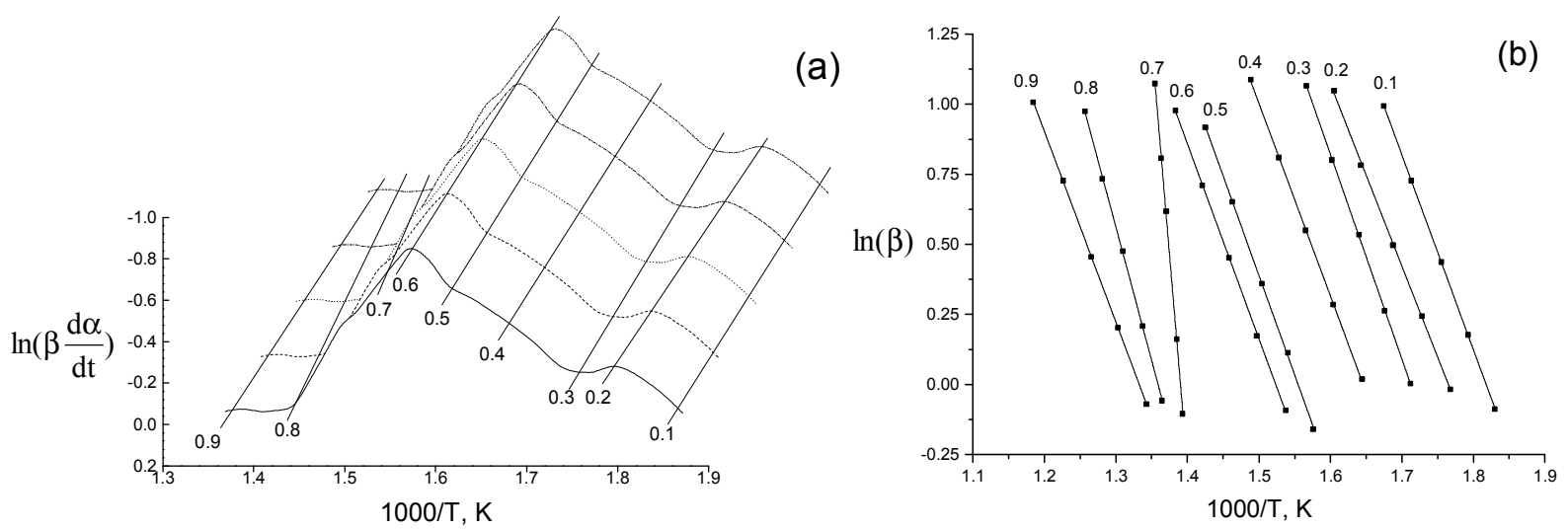

Figure 3. Graphical results of analysis determined by the methods of Friedman (a), Flynn-Ozawa-Wall $(b)$ for $\mathrm{CO}_{2}$-extract distilled from Scabiosa ochroleuca (cream scabious) at heating rates from 5 to $25 \mathrm{deg} / \mathrm{min}$

Obtained values of activation energy that depends on conversion degree correspond to the fourth process and they are presented in the Table 3 .

$\mathrm{Table} 3$

Kinetic parameters according methods of Friedman and Ozawa-Flynn-Wall at different heating rates

(a) Scabiosa ochroleuca (cream scabious)

\begin{tabular}{|c|c|c|c|c|c|c|c|c|}
\hline \multirow{2}{*}{$\alpha$} & \multicolumn{4}{|c|}{ Friedman method } & \multicolumn{4}{|c|}{ Ozawa-Flynn-Wall method } \\
\cline { 2 - 9 } & $E_{a}, \mathrm{~kJ} / \mathrm{mol}$ & $\delta_{(E)}$ & $\ln \mathrm{A} \times 10^{3}, \mathrm{~min}^{-1}$ & $r$ & $E_{a}, \mathrm{~kJ} / \mathrm{mol}$ & $\delta_{(E)}$ & $\ln \mathrm{A} \times 10^{3}, \mathrm{~min}^{-1}$ & $r$ \\
\hline 0.1 & 42.89 & 0.02 & 14.62 & 0.99 & 40.25 & 0.02 & 15.11 & 0.99 \\
\hline 0.2 & 53.31 & 0.26 & 12.20 & 0.96 & 50.75 & 0.22 & 12.47 & 0.96 \\
\hline 0.3 & 57.25 & 0.02 & 10.08 & 0.98 & 54.85 & 0.02 & 10.45 & 0.98 \\
\hline 0.4 & 68.65 & 0.27 & 8.97 & 0.97 & 65.57 & 0.24 & 9.24 & 0.97 \\
\hline 0.5 & 70.83 & 0.02 & 6.94 & 0.99 & 68.17 & 0.02 & 7.41 & 0.99 \\
\hline 0.6 & 81.47 & 0.15 & 5.00 & 0.98 & 79.30 & 0.14 & 5.54 & 0.98 \\
\hline 0.7 & 91.23 & 0.02 & 3.92 & 0.99 & 88.69 & 0.02 & 4.47 & 0.99 \\
\hline 0.8 & 101.24 & 0.16 & 2.31 & 0.98 & 98.58 & 0.11 & 2.84 & 0.98 \\
\hline 0.9 & 104.87 & 0.02 & 1.30 & 0.99 & 101.99 & 0.02 & 1.88 & 0.99 \\
\hline
\end{tabular}

(b) Scabiosa isetensis (lomelosia isetensis)

\begin{tabular}{|c|c|c|c|c|c|c|c|c|}
\hline \multirow{2}{*}{$\alpha$} & \multicolumn{4}{|c|}{ Friedman method } & \multicolumn{4}{c|}{ Ozawa-Flynn-Wall method } \\
\cline { 2 - 10 } & $E_{a}, \mathrm{~kJ} / \mathrm{mol}$ & $\delta_{(E)}$ & $\ln \mathrm{A} \times 10^{3}, \mathrm{~min}^{-1}$ & $r$ & $E_{a}, \mathrm{~kJ} / \mathrm{mol}$ & $\delta_{(E)}$ & $\ln \mathrm{A} \times 10^{3}, \mathrm{~min}^{-1}$ & $r$ \\
\hline 0.1 & 41.32 & 0.02 & 15.83 & 0.99 & 40.97 & 0.02 & 16.71 & 0.99 \\
\hline 0.2 & 51.22 & 0.16 & 13.21 & 0.96 & 50.47 & 0.22 & 14.29 & 0.96 \\
\hline 0.3 & 55.72 & 0.02 & 11.27 & 0.98 & 54.17 & 0.02 & 12.17 & 0.98 \\
\hline 0.4 & 66.71 & 0.17 & 10.43 & 0.97 & 65.27 & 0.14 & 11.12 & 0.97 \\
\hline 0.5 & 69.36 & 0.02 & 8.23 & 0.99 & 67.69 & 0.12 & 9.10 & 0.99 \\
\hline 0.6 & 80.31 & 0.90 & 6.19 & 0.98 & 81.12 & 0.01 & 7.09 & 0.98 \\
\hline 0.7 & 89.87 & 0.02 & 5.11 & 0.99 & 88.34 & 0.02 & 6.11 & 0.99 \\
\hline 0.8 & 99.23 & 0.10 & 3.22 & 0.98 & 99.31 & 0.10 & 4.23 & 0.98 \\
\hline 0.9 & 103.06 & 0.02 & 2.56 & 0.99 & 102.71 & 0.07 & 3.41 & 0.99 \\
\hline
\end{tabular}

Note. $\alpha$ - conversion degrees; $E_{a}$ - activation energy; $\delta_{(E)}-$ is the relative error of the experimental dot; $A-$ preexponential factor; $r$ - is the correlation coefficient.

Values of activation energy (Table 3) are differed on $0.4-0.6 \%$, thus, mathematical exactness of applied methods is satisfactory. Values of relative error $(\sigma)$ (Table 3) certify high exactness as well. Analysis showed that attained kinetic dependences were described the most adequately within the framework of model $\mathrm{F}_{1}$ (first-order dependence in relation to $\delta$ ). 
For kinetic analysis of thermal destruction process of studied samples was also used the method of nonparametric kinetics. Method of nonparametric kinetics (NPK) $[10,11]$ is particular approach for kinetic data processing. The method is new point of view of kinetic analysis based on the rounding the results of stadial process kinetics. Experimental values of reactions rates are located in the matrix which is expressed as product of two vectors containing the information on $k(T)$ and $g(\alpha)$. Actually, this mathematical model is the result of equation (1).

$$
r=g(\alpha) \cdot k(T) .
$$

Method of NPK is based on the use the algorithm of singular value decomposition (SVD) for M-matrix decomposition into two vectors [11]. M-matrix can be analyzed in a certain way:

$$
M=U(\operatorname{diag} \cdot S) \cdot V^{T} \text {. }
$$

The most significant peculiarity of this method is that it can decomposes submatrix in regard to temperature (V) and conversion function (U), there is no need to make any to make any suggestions about their functionality. Data were obtained during the analysis of vector $u$ (first column $\mathrm{U}$ ) in regard to kinetic model presented by Šestak and Berggren [11]: $g(\alpha)=\alpha^{m}(1-\alpha)^{n}$, so, the vector $v$ (first column V) - temperature dependence $T$ in Arrhenius equations. Meaning of explained variation $\lambda$, expresses the contribution of each of simultaneous stages for whole process of thermal decomposition, therefore, $\sum \lambda_{i}=100 \%$.

Results of NPK method are systematized in the Table 4, dependence of reaction rate $\left(\frac{d \alpha}{d T}\right)$ from temperature $(T)$ and conversion degrees $(\alpha)$ were interpolated as the surfaces in three-dimensional space (Fig. 4).

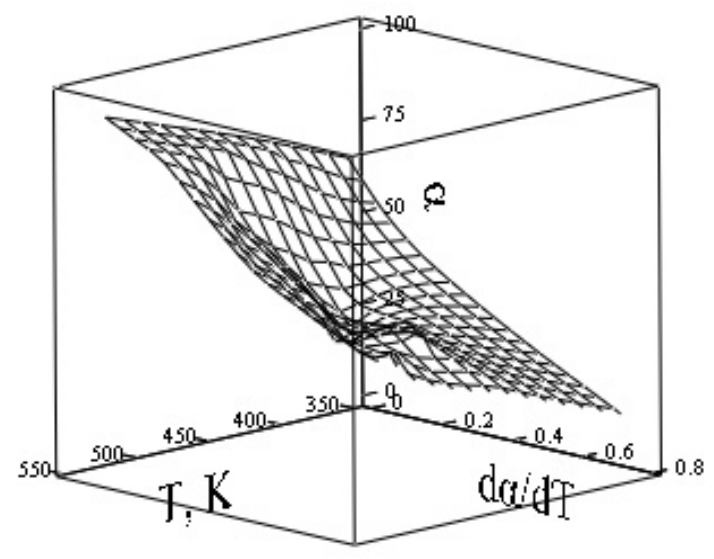

Figure 4. Surface of $\mathrm{CO}_{2}$-extract distilled from Scabiosa ochroleuca in three-dimensional space: dependence of reaction rate $(d \alpha / d T)$ from temperature $(T)$ and conversion degree $(\alpha)$ in air

Table 4

Kinetic parameters of thermal decomposition of $\mathrm{CO}_{2}$-extracts: Scabiosa ochroleuca, Scabiosa isetensis

\begin{tabular}{|c|c|c|c|c|c|c|c|c|}
\hline \multicolumn{2}{|c|}{ Sample } & $\begin{array}{l}\lambda, \\
\%\end{array}$ & $\begin{array}{c}E_{a}, \\
\mathrm{~kJ} / \mathrm{mol}\end{array}$ & $\begin{array}{l}A, \\
\mathrm{~s}^{-1}\end{array}$ & $n$ & $m$ & $\begin{array}{l}\text { Šestak-Berggren } \\
g(\alpha)=\alpha^{m}(1-\alpha)^{n}\end{array}$ & $\begin{array}{c}\sum \lambda \cdot \mathrm{E}_{a}, \\
\mathrm{~kJ} / \mathrm{mol}\end{array}$ \\
\hline \multirow{4}{*}{$\begin{array}{c}\text { Scabiosa } \\
\text { ochroleuca }\end{array}$} & 1 & 57.1 & 30.41 & $1.23 \times 10^{7}$ & 1 & - & $(1-\alpha)$ & \multirow{4}{*}{$107.51 \pm 1.8$} \\
\hline & 2 & 27.0 & 51.87 & $1.03 \times 10^{14}$ & - & $1 / 3$ & $\alpha^{1 / 3}$ & \\
\hline & 3 & 11.3 & 77.93 & $1.37 \times 10^{22}$ & 2 & 1 & $\alpha(1-\alpha)^{2}$ & \\
\hline & 4 & 4.6 & 99.52 & $1.71 \times 10^{28}$ & $4 / 5$ & $1 / 3$ & $(1-\alpha)^{4 / 5} \alpha^{1 / 3}$ & \\
\hline \multirow{4}{*}{$\begin{array}{c}\text { Scabiosa } \\
\text { isetensis }\end{array}$} & 1 & 59.7 & 34.64 & $2.04 \times 10^{11}$ & 0.1 & - & $(1-\alpha)^{0,1}$ & \multirow{4}{*}{$108.04 \pm 2.2$} \\
\hline & 2 & 22.5 & 68.05 & $1.40 \times 10^{18}$ & - & 0.1 & $\alpha^{0.1}$ & \\
\hline & 3 & 13.3 & 87.54 & $0.70 \times 10^{21}$ & 2 & 1 & $\alpha(1-\alpha)^{2}$ & \\
\hline & 4 & 4.5 & 101.43 & $1.95 \times 10^{23}$ & $1 / 3$ & $2 / 4$ & $\alpha^{1 / 3}(1-\alpha)^{2 / 4}$ & \\
\hline
\end{tabular}
were evaluated with the use of the method of nonparametric kinetics (NPK) 


\title{
Conclusions
}

Simultaneous use of data of TG/DTG/HF methods for kinetic analysis provide us with complete picture of thermal decomposition of carbonic extracts samples obtained from Scabiosa ochroleuca (cream scabious) and Scabiosa isetensis (lomelosia isetensis). It makes possible to evaluate the kinetic parameters using different kinetic methods, to compare the values activation energy obtained from various experimental data (TG, DTG and HF). Kinetic parameters were estimated with the use of methods of Friedman, Flynn-OzawaWall, and method of nonparametric kinetics (NPK).

It is evident that obtained values of activation energy and thermodynamic characteristics allow us to forecast the composition, also they may be used as fiducial marks at the standardization of samples of $\mathrm{CO}_{2}$-extracts.

\section{References}

1 Боголицын К.Г. Современные тенденции в химии и химической технологии растительного сырья / К.Г. Боголицын // Рос. хим. журн. - 2004. - Т. 6, № 48. - С. 105.

2 Шелдон Р.А. Каталитические превращения в воде и сверхкритическом диоксиде углерода с позиций концепции устойчивого развития / Р.А. Шелдон // Рос. хим. журн. — 2004. — Т. 6, № 48. — С. 74.

3 Лебедев Ю.А. Роль термодинамики как основы развития фундаментальных исследований, стандартизации и технологий / Ю.А. Лебедев, В.К. Абросимов, В.И. Веденеев, А.Н. Кизин, Е.А. Лебедева, Ю.Е. Мошкин, Ю.Д. Орлов, С.В. Серков. - М.: ИКЦ Академкнига, 2007. - 127 с.

4 Zhunusova M.A. Constituent composition and biological activity of $\mathrm{CO}_{2}$-extracts of Scabiosa isetensis and Scabiosa ochroleuca / M.A. Zhunusova, E.M. Suleimen, Zh.B. Iskakova, M.Yu. Ishmuratova, R.M. Abdullabekova // Chemistry of Natural Compounds. - 2017. — Vol. 53, No. 4. - P. 775-777.

5 Казицына Л.А. Применение ИК-, УФ-, ЯМР-спектроскопии в органической химии: учеб. пособие для вузов / Л.А. Казицына, Н.Б. Куплетская. - М.: Высш. шк., 1971. — 264 с.

6 Friedman H.L. Kinetic of thermal degradation of char-forming plastics from thermogravimetry. Application to a phenolic plastic / H.L. Friedman // Journal of Polymer Science Polymer Symposium. — 1964. — No. 6. — P. 183-195. doi:10.1002/ polc.5070060121.

7 Flynn J.H. A quick, direct method for the determination of activation energy from thermogravimetric data / J.H. Flynn, L.A. Wall // Journal of Polymer Science Part C: Polymer Letters. - 1966. — Vol. 5, No. 4. - P. 323-328. doi: 10.1002/ pol.1966.110040504.

8 Wall M.E. Singular Value Decomposition and Principal Component Analysis / M.E. Wall, A. Rechtsteiner, L.M. Rocha // A practical approach to microarray data analysis. - 2003. - No. 9. - P. 91-109.

9 Sempere J. Progress in Non-parametric Kinetics / J. Sempere, R. Nomen, R. Serra // Journal of Thermal Analysis and Calorimetry. — 1999. - Vol. 2, No. 56. — P. 843. doi: 10.1023/A:1010178827890.

10 Fedyukhin A.V. Comparison of kinetic models of biomass thermal decomposition: Book of Abstracts of International Conference on Interaction of Intense Energy Fluxes with Matter (March 1-6, 2011) / A.V. Fedyukhin, I.L. Maikov, V.A. Sinelshchikov. - Moscow; Chernogolovka; Nalchik, 2011. - P. 114.

11 Albu P. Kinetics of degradation under non-isothermal conditions of a thermooxidative stabilized polyurethane / P. Albu, C. Bolcu, G. Vlase, N. Doca, T. Vlase // Journal of thermal analysis and calorimetry. — 2011. — Vol. 2, No. 105. — P. 685-689. doi: 10.1007/s10973-011-1497-6.

\section{М.А. Жунусова, А.Ж. Сарсенбекова, Р.М. Абдуллабекова, И.В. Фигуринене Scabiosa isetensis және Scabiosa ochroleuca $\mathrm{CO}_{2}$-экстракт үлгілерінің әртүрлі жылдамдықта термиялық ыдырауларының салыстырмалы кинетикалық талдауы}

\begin{abstract}
Динамикалық термогравиметрия мәліметтері негізінде Scabiosa isetensis және Scabiosa ochroleuca $\mathrm{CO}_{2}$-экстракт үлгілерінің термиялық ыдырауының кинетикалық параметрлерін есептеу әдістерінің сараптамасы ұсынылды. Осы мақсаттағы зерттеулер сыналатын үлгіні ауа атмосферасында әртүрлі жылдамдықпен қыздыру әдісі арқылы жүргізілді: 5-25 град/мин. Әртүрлі эксперименталды мәліметтерден (TG/DTG/HF) алынған деректер кинетикалық параметрлерді алуға бағытталған Фридман және Флинн-Озава-Уолл кинетикалық модельдеріне сәйкес өңделді. Жоғарыда аталған модельдерді қолдану сыналатын үлгінің әртүрлі жылдамдықта қызған шағындағы және конверсиялану дәрежесі жағдайындағы белсендірілген энергиясының көрсеткіштерін және экспоненциалды көбейткіштерін графикалық түрде анықтауға мүмкіндік берді. Термиялық деструкциямен қатар жүретін кешенді процестерді объективті бағалау үшін параметрлік емес кинетика әдісі (ПЕК) пайдаланылды. ПЕК кинетикалық деректерді өңдеудің ерекше тәсілі болып табылады. Яғни, бұл әдіс бір кезеңдік үдерістің кинетикалық талдау нәтижелерінің көрсеткіштерін дөңгелектеуге негізделгендіктен, кинетикалық
\end{abstract}


талдауға деген жаңа көзқарасты қалыптастырып отыр. Осылайша, кинетикалық талдау жүргізу мақсатында TG/DTG/HF деректерін бір мезгілде қолдану бізге Scabiosa isetensis (ақшыл сары скабиоза) және Scabiosa ochroleuca (исет скабиозасы) көміртегі диоксидінің экстракт үлгілерінің термодеструкцияға ұшырау процесі жайлы толық мағлұмат алуға мүмкіндік береді. Зерттеу нәтижесі әртүрлі әдістермен анықталған кинетикалық параметрлердің өзара үйлесімділігін көрсетіп отыр.

Кілт сөздер: $\mathrm{CO}_{2}$-экстракт, Scabiosa ochroleuca, Scabiosa isetensis, термиялық сараптама, термодеструкция, кинетикалық параметрлер, изоконверсионды әдіс, параметрлік емес кинетика.

\title{
М.А. Жунусова, А.Ж. Сарсенбекова, Р.М. Абдуллабекова, И.В. Фигуринене
}

\section{Сравнительный анализ кинетики термического разложения образцов углекислотного экстракта из Scabiosa ochroleuca и Scabiosa isetensis при различных скоростях нагрева}

\begin{abstract}
Представлен анализ различных методов расчета кинетических параметров терморазложения образцов $\mathrm{CO}_{2}$-экстрактов из Scabiosa ochroleuca и Scabiosa isetensis по данным динамической термогравиметрии. Исследования были произведены в атмосфере воздуха при различных скоростях нагрева: 5-25 град/мин. Результаты, полученные из различных экспериментальных данных (TG/DTG/HF), были обработаны в соответствии со следующими кинетическими моделями: Фридмана, Флинна-Озавы-Уолла с тем, чтобы получить кинетические параметры. Применение перечисленных выше моделей позволило графически установить эффективные значения энергии активации и предэкспоненциальный множитель при различных скоростях нагрева образца и степенях конверсии. Для объективной оценки сложных процессов, протекающих параллельно термической деструкции, использовали метод непараметрической кинетики (НПК). НПК представляет собой особый подход для обработки кинетических данных, т.е. новую точку зрения на кинетический анализ, который основан на округлении результатов кинетики одностадийного процесса. Таким образом, одновременное использование данных TG/DTG/HF для кинетического анализа дает нам более полную картину термодеструкции образцов углекислотного экстракта из Scabiosa ochroleuca (скабиоза бледно-желтая) и Scabiosa isetensis (скабиоза исетская). В результате исследования было показано, что значения кинетических параметров, определенные разными методами, хорошо согласуются между собой.
\end{abstract}

Ключевые слова: $\mathrm{CO}_{2}$-экстракт, Scabiosa ochroleuca, Scabiosa isetensis, термический анализ, термодеструкция, кинетические параметры, изоконверсионный метод, непараметрическая кинетика.

\section{References}

1 Bogolitsyn, K.G. (2004). Sovremennye tendentsii v khimii i khimicheskoi tekhnolohii rastitelnoho syria [Modern trends in the chemical and chemical technology of plant raw materials]. Rossiiskii khimicheskii zhurnal - Russian Chemical Journal, 6, 48, 105-123 [in Russian].

2 Sheldon, R.A. (2004). Kataliticheskie prevrashcheniia v vode i sverkhkriticheskom diokside uhleroda s pozitsii kontseptsii ustoichivoho razvitiia [Catalytic transformations in water and supercritical carbon dioxide from the standpoint of the concept of sustainable development]. Rossiiskii khimicheskii zhurnal - Russian Chemical Journal, 6, 48, 74-83 [in Russian].

3 Lebedev, Yu.A., Abrosimov, V.K., Vedeneev, V.I., Kizin, A.N., Lebedeva, E.A., \& Moshkin, Yu.E., et al. (2007). Rol termodinamiki kak osnovy dlia razvitiia fundamentalnoho issledovaniia, standartizatsii i tekhnolohii [The role of thermodynamics as a basis for the development of fundamental research, standardization and technology]. Moscow: Akademkniha [in Russian].

4 Zhunusova, M.A., Suleimen, E.M., Iskakova, Zh.B., Ishmuratova, M.Yu., \& Abdullabekova, R.M. (2017). Constituent composition and biological activity of $\mathrm{CO}_{2}$-extracts of Scabiosa isetensis and Scabiosa ochroleuca. Chemistry of Natural Compounds, 53(4), 775-777.

5 Kazitsyna, L.A., \& Kupletskaya, N.B. (1971). Primenenie UF-, IK-, YaMR-spektroskopii v orhanicheskoi khimii [Application of $U V$-, IR-, NMR-, and Mass-spectroscopy in organic chemistry]. Moscow: Vysshaia shkola [in Russian].

6 Friedman, H.L. (1964). Kinetic of thermal degradation of char-forming plastics from thermogravimetry. Application to a phenolic plastic. Journal of Polymer Science Polymer Symposium, 6, 183-195. doi:10.1002/polc.5070060121.

7 Flynn, J.H., \& Wall, L.A. (1966). A quick, direct method for the determination of activation energy from thermogravimetric data. Journal of Polymer Science Part C: Polymer Letters, 5(4), 323-328. doi: 10.1002/pol.1966.110040504.

8 Wall, M.E., Rechtsteiner, A., \& Rocha, L.M. (2003). Singular Value Decomposition and Principal Component Analysis. In A practical approach to microarray data analysis, 9, 91-109.

9 Sempere, J., Nomen, R., \& Serra, R. (1999). Progress in Non-parametric Kinetics. Journal of Thermal Analysis and Calorimetry, 2(56), 843. doi: 10.1023/A:1010178827890.

10 Fedyukhin, A.V., Maikov, I.L., \& Sinelshchikov, V.A. (2011). International Conference on Interaction of Intense Energy Fluxes with Matter, Moscow, March 1-6, 2011. Moscow; Chernogolovka; Nalchik.

11 Albu, P., Bolcu, C., Vlase, G., Doca, N., \& Vlase, T. (2011). Kinetics of degradation under non-isothermal conditions of a thermooxidative stabilized polyurethane. Journal of Thermal Analysis and Calorimetry, 2(105), 685-689. doi: 10.1007/s10973-011$1497-6$ 